\title{
Penyebaran Dan Karakteristik Habitat Jenis Rasamal (Altingia excelsa Noronha) di Taman Nasional Gunung Halimun Salak
}

\author{
Distribution and Habitat Characteristics of Rasamala (Altingia excelsa Noronha) in Halimun \\ Salak Mountain National Park
}

Istomo $^{\mathrm{a}}$ dan Putri Novita Sari ${ }^{\mathrm{b}}$

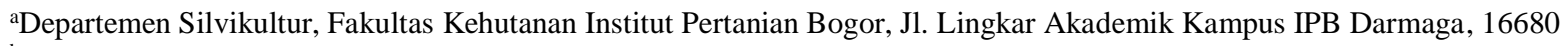

bAlumnus Departemen Silvikultur, Fakultas Kehutanan Institut Pertanian Bogor, Kampus IPB Darmaga Bogor, 16680

\section{Article Info:}

Received: 22 - 02 - 2018

Accepted: 31 - $01-2019$

Keywords:

Distribution pattern, habitat characteristics, Halimun Salak Mountain National Park, rasamala (A. excelsa)

Corresponding Author: Istomo

Fakultas Kehutanan Institut Pertanian Bogor, Jl. Lingkar Akademik Kampus IPB Darmaga 16680;

Email: istomo19@gmail.com

\begin{abstract}
Rasamala (Altingia excelsa Noronha) is one of the primary species in Halimun Salak Mountain National Park that grows in the lower mountain forests. In addition to the value of conservation, almost all parts of rasamala species can be utilized such as wood, leaves, fruit, and the canopy as a bird habitat. Information of natural distribution and habitat of rasamala are needed for conservation and cultivation purposes. The objectives of this research are to identify the distribution pattern and habitat characteristics of rasamala in Halimun Salak Mountain National Park. Research was done by make square plots with $30 \times 30 \mathrm{~m} 2$ size that spread in the area of Halimun Montain 15 plots and Salak Mountain 15 plots. The analysis used morisita index to know the distribution pattern of rasamala and linear regression analysis to determine the influence of environmental factors. The result showed that distribution pattern of rasamala was clumped. Environmental factors that affect the existence of rasamala encompass altitude above sea level, slope, temperature, humidity, soil C-organic content, and N-total where the most influential factor is the $N$-total content of the soil. $F$ test results on regression showed that the variables tested in Resort Cikaniki simultaneously had no significant effect on rasamala density, while the variables tested at Kawah Ratu Resort had significant effect on rasamala density.
\end{abstract}

How to cite (CSE Style $8^{\text {th }}$ Edition):

Istomo dan Sari PN. Penyebaran dan karakteristik habitat jenis rasamal (Altingia excelsa Noronha) di Taman Nasional Gunung Halimun Salak. JPSL 9(3): 608-625. http://dx.doi.org/10.29244/jps1.9.3.608-625.

\section{PENDAHULUAN}

\section{Latar Belakang}

Kawasan Taman Nasional Gunung Halimun Salak (TNGHS) merupakan perwakilan tipe ekosistem hutan hujan dataran rendah, hutan submontana, dan hutan montana di Pulau Jawa yang memiliki peranan penting sebagai sistem penyangga kehidupan. Kawasan ini menyimpan keanekaragaman hayati yang tinggi dan merupakan perlindungan fungsi hidrologis di Kabupaten Bogor, Lebak dan Sukabumi (Carolyn et al. 2013). Penelitian Yusuf (2004) menyatakan bahwa, beberapa tempat di Kawasan Gunung Halimun telah mengalami gangguan, dimana salah satunya diakibatkan oleh tekanan masyarakat, sehingga sebagian kawasan didominasi oleh jenis-jenis hutan sekunder dan jenis eksotis sedangkan beberapa jenis primer semakin langka dan hanya dijumpai berupa anakannya. 
Salah satu jenis primer di kawasan Taman Nasional Gunung Halimun Salak adalah rasamala (Altingia excelsa), yang selain mempunyai nilai konservasi juga bernilai ekonomi. Rasamala termasuk dalam famili Hamamelidaceae yang terdiri atas 8 spesies, tersebar dari Tibet Selatan, Assam (India), dan Asia Tenggara termasuk Cina Selatan sampai Malesia. Namun, hanya terdapat 1 jenis yang ada di Malesia yaitu A. excelsa. Jenis ini menyebar mulai dari Himalaya menuju wilayah lembab di Myanmar hingga Semenanjung Malaysia, Sumatera, dan Jawa (Soerianegara dan Lemmens 1994). Penyebaran rasamala secara alami di Indonesia meliputi Sumatra Utara, Sumatra Barat, Bengkulu, dan Jawa Barat. Keberadaan rasamala di beberapa daerah memiliki nama yang berbeda di antaranya rasamala (Jawa Barat), gadog (Jawa), tulason (Tapanuli), lamin, mandung, mandung jati atau sigadundeung (Minangkabau), dan cemara hitam (Palembang). Rasamala di Jawa Barat tumbuh pada ketinggian 500-1500 mdpl pada daerah-daerah dengan musim kering basah atau sedang dan tumbuh tersebar pada ketinggian 600-1600 mdpl pada tanah yang subur dan selalu lembab (Hidayah 2011).

Pohon rasamala selalu hijau, tinggi mencapai 40-60 m dengan tinggi bebas cabang 20-35 m, diameter hingga 80-150 cm (Pramono dan Djam'an 2002).Umumnya rasamala mendominasi bagian hutan pegunungan bawah bersama dengan jenis puspa (Schima wallichii) dan pasang (Quercus spp. dan Lithocarpus spp.) (Sadili 2011). Berdasarkan penelitian Hidayat dan Fijridiyanto (2002), keberadaan rasamala biasanya dimanfaatkan oleh masyarakat sebagai bahan bangunan karena kayunya yang awet, daun rasamala juga sering dimakan sebagai lalab maupun sebagai bahan pengobatan alami. Selain itu, buahnya dapat dimakan oleh monyet dan burung maupun pohonnya yang dapat menjadi habitat jenis burung-burung tertentu.

Banyaknya penelitian mengenai rasamala di TNGHS sampai saat ini baru membahas mengenai kondisi vegetasi, seperti jenis dominan dan pemanfaatannya. Akan tetapi, penelitian mengenai keberadaan rasamala secara ekologinya masing jarang. Menurut Wibowo (2006), untuk keperluan konservasi suatu jenis baik secara in situ maupun ex situ diperlukan informasi mengenai penyebaran alami dan tempat tumbuhnya. Oleh karena itu, diperlukan penelitian mengenai penyebaran jenis dan habitat rasamala agar dapat digunakan sebagai dasar pembinaan dan pelestariannya.

\section{Tujuan Penelitian}

Penelitian ini bertujuan untuk mengidentifikasi pola sebaran dan karakteristik habitat jenis rasamala $(A$. excelsa) serta hubungan antara keberadaan rasamala dengan faktor fisik lingkungan di Taman Nasional Gunung Halimun Salak.

\section{METODE}

\section{Waktu dan Lokasi Penelitian}

Penelitian ini dilakukan pada bulan Mei-September 2017. Pengambilan data dilakukan di hutan primer kawasan Gunung Halimun yang bertempat di Resort Cikaniki dan kawasan Gunung Salak yang bertempat di Resort Kawah Ratu pada bulan Mei-Juni. Selanjutnya, analisis sampel tanah dilakukan di Laboratorium Pengaruh Hutan dan Laboratorium Ilmu Tanah dan Sumberdaya Lahan IPB.

\section{Alat dan Bahan}

Alat-alat yang digunakan dalam penelitian ini adalah peta kawasan, kompas, GPS, clinometer, golok, patok, tali rafia, pita ukur, meteran jahit, hagameter, kamera digital, spidol, kertas label, trashbag bening, bor tanah, termometer dry-wet, dan tally-sheet. Bahan-bahan yang diamati meliputi pohon dan permudaan jenis rasamala (A. excelsa), pohon dan permudaan jenis lain yang ada di plot pengamatan, dan faktor-faktor lingkungan. 


\section{Data yang Dikumpulkan}

Data yang dikumpulkan berupa data primer dan sekunder. Data primer meliputi data struktur dan komposisi hutan khususnya jenis rasamala (A.excelsa), ketinggian tempat (mdpl), kelerengan (\%), sifat fisik dan kimia tanah, serta suhu dan kelembaban udara. Data sekunder yang dikumpulkan berupa wawancara, studi pustaka, dan informasi lain terkait kondisi umum lapangan yang meliputi: sejarah kawasan, letak, luas, kondisi tanah, topografi, iklim, kondisi vegetasi, satwa, dan kondisi masyarakat sekitar kawasan hutan.

\section{Prosedur Penelitian}

\section{Penentuan Pengambilan Sampel}

Lokasi pengambilan contoh ditentukan berdasarkan keberadaan jenis rasamala di hutan primer kawasan Taman Nasional Gunung Halimun Salak (TNGHS). Metode yang digunakan yaitu dengan pembuatan petak contoh berbentuk kuadrat ukuran 30x30 m² sebanyak 30 petak yang disebar di dua lokasi yaitu 15 petak di kawasan Gunung Halimun (Resort Cikaniki) dan 15 petak di kawasan Gunung Salak (Resort Kawah Ratu) (Bramasto 2008; Kusmana 1997; Wibowo 2006). Peta dan lokasi petak contoh untuk penelitian rasamala di TNGHS ditampilkan pada Gambar 1.

\section{Pengambilan Data Lapangan}

Data yang diperlukan meliputi vegetasi, tanah, dan sifat fisik lingkungan. Data vegetasi yang dianalisis yaitu semai $\left(2 \times 2 \mathrm{~m}^{2}\right)$, pancang $\left(5 \times 5 \mathrm{~m}^{2}\right)$, tiang $\left(10 \times 10 \mathrm{~m}^{2}\right)$, dan pohon $\left(30 \times 30 \mathrm{~m}^{2}\right)$ (Kusmana, 1997). Data vegetasi semai dan pancang yang diambil berupa nama jenis dan jumlah individu, sedangkan data vegetasi tiang dan pohon yang diambil berupa nama jenis, diameter, dan tinggi total, sedangkan khusus jenis rasamala dilakukan survei pada ukuran petak 30x30 $\mathrm{m}^{2}$ untuk semua tingkat pertumbuhan.

Contoh sampel tanah diambil pada setiap lokasi pengamatan dari lima titik dalam plot pengamatan pada kedalaman 0-40 cm dengan menggunakan bor tanah. Sampel tanah kemudian dikompositkan untuk dianalisis sifat fisik dan kimianya. Pengukuran suhu dilakukan di bawah naungan dalam plot pengamatan menggunakan termometer dry-wet.

\section{Analisis Data}

\section{Analisis Vegetasi}

1. Rumus untuk perhitungan INP (Mueller-Dombois dan Ellenberg 1974):

$$
\begin{aligned}
\mathrm{K} & =\frac{\text { Jumlah individu suatu jenis }}{\text { Luas total petak contoh }} \\
\mathrm{KR} & =\frac{\text { Jumlah petak ditemukan suatu jenis }}{\text { Jumlah seluruh petak contoh }} \times 100 \% \\
\mathrm{~F} & =\frac{\text { Jumlah petak ditemukan suatu jenis }}{\text { Jumlah seluruh petak contoh }} \\
\mathrm{FR} & =\frac{\text { Frekuensi suatu jenis }}{\text { Frekuensi seluruh jenis }} \times 100 \% \\
\mathrm{D} & =\frac{\text { Jumlah LBDS suatu jenis }}{\text { Luas Petak contoh }} \\
\mathrm{DR} & =\frac{\text { Dominansi suatu jenis }}{\text { Dominansi semua jenis }} \times 100 \% \\
\mathrm{INP} & =\mathrm{R}+\mathrm{FR} \text { (tingkat semai, tumbuhan bawah, dan pancang) } \\
\mathrm{INP} & =\mathrm{KR}+\mathrm{FR}+\text { DR(tingkat tiang dan pohon) }
\end{aligned}
$$


2. Rumus indeks dominansi (Ludwig dan Reynolds 1988):

$$
\mathrm{ID}=\sum\left(\frac{n i}{N}\right)^{2}
$$

3. Rumus indeks keanekaragaman jenis (Ludwig dan Reynolds 1988):

$$
\mathrm{H}^{\prime}=-\sum\left(\frac{n i}{N} \ln \frac{n i}{N}\right)
$$

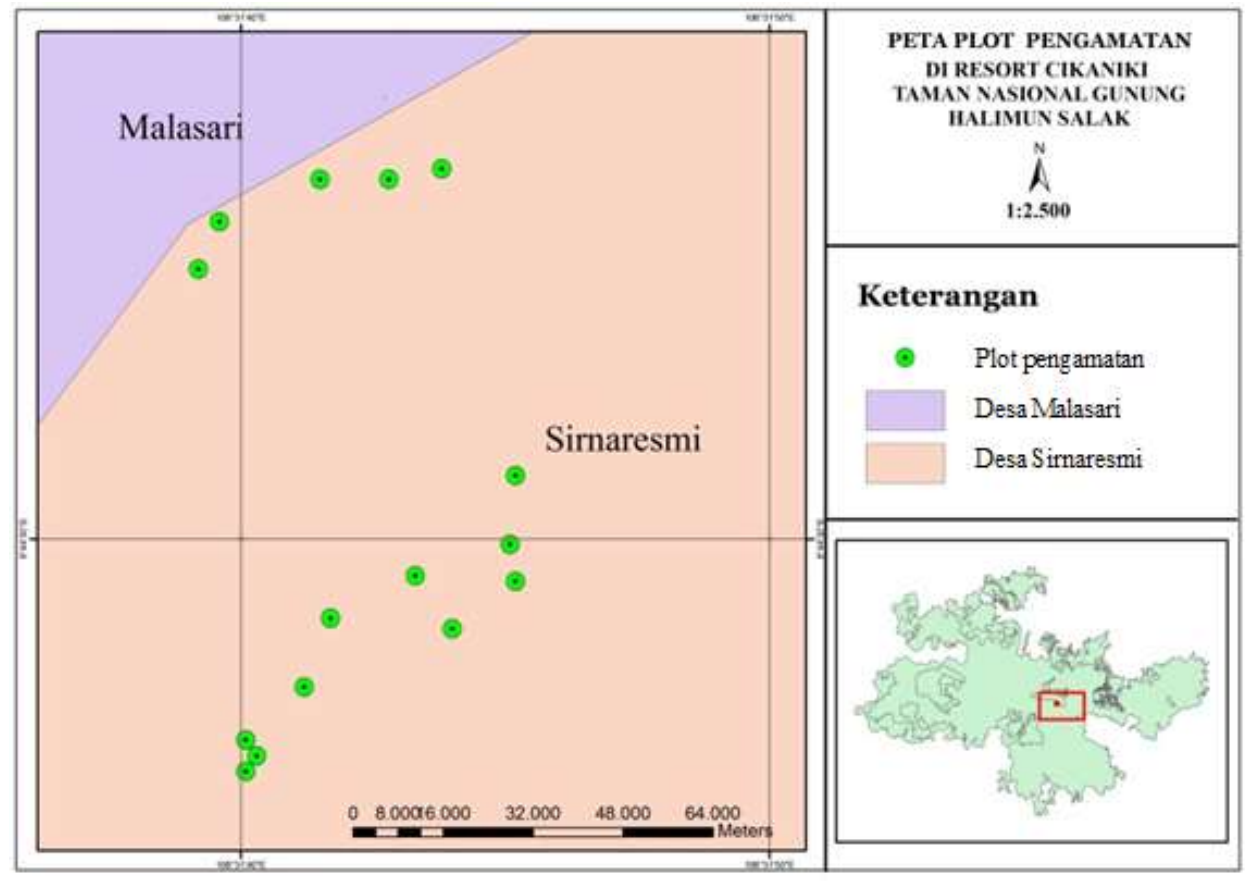

(a)

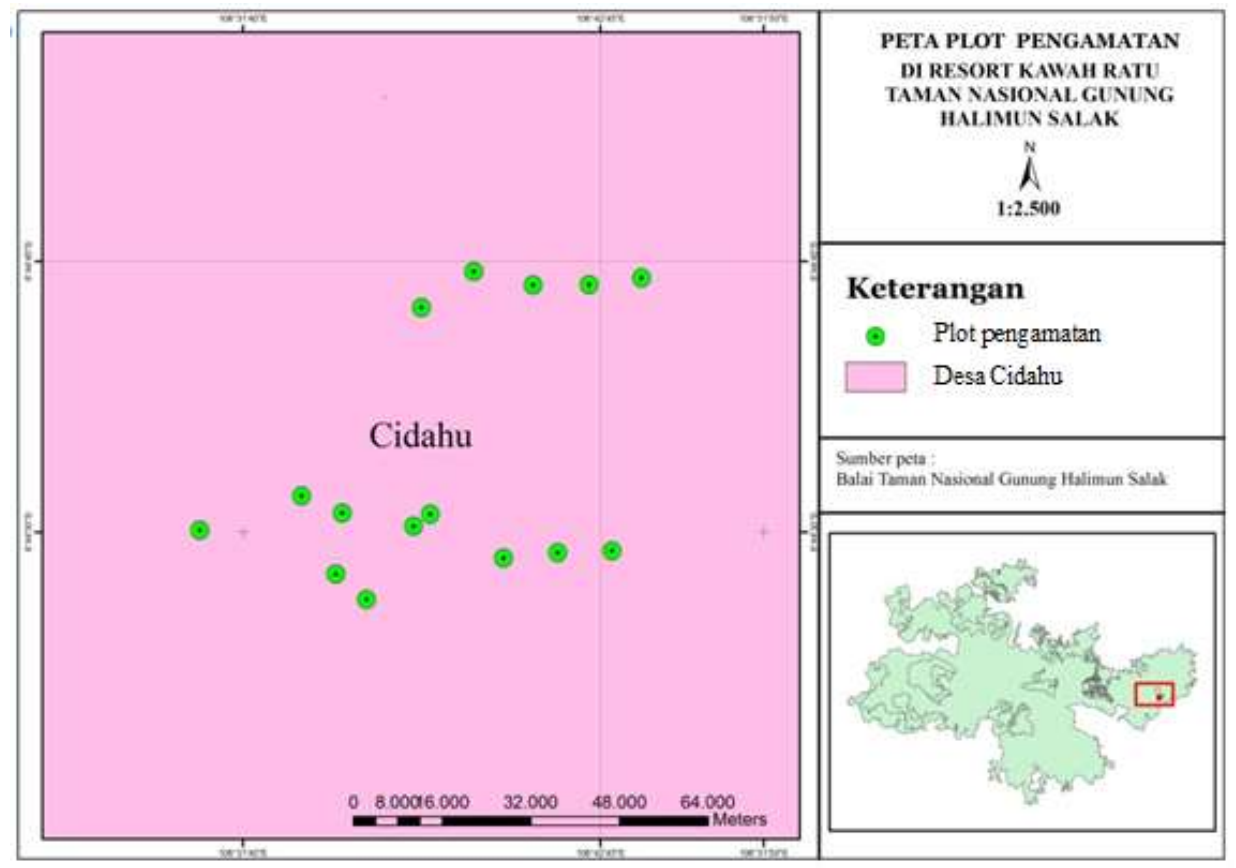

(b)

Gambar 1 Peta plot pengamatan di (a) Resort Cikaniki dan (b) Resort Kawah Ratu 
4. Rumus indeks kemerataan (Ludwig dan Reynolds 1988):

$$
\mathrm{E}=\frac{\mathrm{H}^{\prime}}{\ln \mathrm{S}}
$$

5. Indeks Kekayaan Jenis Margalef (Ludwig dan Reynolds 1988; Magurran 2004):

$$
\mathrm{R}=\frac{\mathrm{S}-1}{\ln \mathrm{N}}
$$

$$
\begin{array}{lll}
\text { Keterangan: } & \text { ID } & : \text { indeks dominansi } \\
& \text { H' } & : \text { indeks keanekaragaman } \\
\mathrm{E} & : & \text { indeks kemerataan } \\
\mathrm{R} & : & \text { indeks kekayaan } \\
\mathrm{ni} & : & \text { indeks nilai penting } \\
\mathrm{ln} & : & \text { logaritma natural } \\
\mathrm{N} & : & \text { total indeks nilai penting } \\
\mathrm{S} & : & \text { jumlah jenis }
\end{array}
$$

6. Indeks Penyebaran Jenis

Pola sebaran spasial suatu spesies dapat diidentifikasi dengan menggunakan Indeks Morisita dan Standarisasi Indeks Morisita (Rani 2003) sebagai berikut:

Menghitung nilai indeks Morisita (I $\delta$ ) (Morisita 1959):

$$
\mathrm{I} \delta=n \frac{\left(\sum x i^{2}-\sum x i\right)}{\left(\sum x i\right)^{2}-\sum x i}
$$

Keterangan: $\quad \mathrm{I} \delta \quad$ : indeks penyebaran Morisita

n : jumlah plot

$\sum \mathrm{xi} \quad$ : jumlah individu tiap plot

$\sum \mathrm{xi}^{2} \quad$ : jumlah individu kuadrat tiap plot

Menghitung Mu dan Mc(Jongjitvimol et al.,2005):

$$
\mathrm{Mu}=\frac{X_{0.975}^{2}-n+\sum x i}{\left(\sum x i\right)-1}
$$

$$
\mathrm{Mc}=\frac{X_{0.025}^{2}-n+\sum x i}{\left(\sum x i\right)-1}
$$

Keterangan: $\mathrm{Mu} \quad$ : indeks penyebaran Morisita untuk polasebaran seragam

$\mathrm{X}^{2}{ }_{0.975}$ : nilai chi-square tabel dengan deraat bebas $\mathrm{n}-1$ dan selang kepercayaan $97.5 \%$

Mc : indeks penyebaran Morisita untuk pola sebaran mengelompok

$\mathrm{X}^{2}{ }_{0.025}$ : nilai chi-square tabel dengan deraat bebas $\mathrm{n}-1$ dan selang kepercayaan $2.5 \%$

Menghitung Standar derajat Morisita (Ip):

$$
\begin{aligned}
& \text { Ip }=0.5+0.5\left(\frac{I \delta-M c}{n-M c}\right) \\
& I p=0.5\left(\frac{I \delta-1}{M c-1}\right)
\end{aligned}
$$$$
\text { ; jika I } \delta \geq \mathrm{Mc}>1.0
$$$$
\text { ; jika } \mathrm{Mc}>\mathrm{I} \delta \geq 1.0
$$ 


$$
\begin{array}{ll}
\text { Ip }=-0.5\left(\frac{\mathrm{I} \delta-1}{\mathrm{Mu}-1}\right) & ; \text { jika } 1.0>\mathrm{I} \delta \geq \mathrm{Mu} \\
\mathrm{Ip}=-0.5+0.5\left(\frac{\mathrm{I} \delta-\mathrm{Mu}}{\mathrm{Mu}}\right) & ; \text { jika } 1.0>\mathrm{Mu} \geq \mathrm{I} \delta
\end{array}
$$

Jika Ip $<0$ maka pola sebarannya seragam. Jika Ip=0 maka pola sebarannya acak, dan jika Ip $>0$ maka pola sebarannya mengelompok.

\section{Analisis Tanah}

Analisis tanah dilakukan terhadap tekstur tanah (pasir, debu, dan liat), kandungan C-organik, N-total, P, K, $\mathrm{pH}$, dan KTK.Analisistanah dilakukan di Laboratorium Ilmu Tanah dan Sumberdaya Lahan dan Laboratorium Pengaruh Hutan IPB.

\section{Hubungan Faktor Lingkungan dengan Keberadaan Rasamala}

Hubungan faktor lingkungan dengan keberadaan rasamala dapat diketahui menggunakan analisis regresi linier berganda. Persamaan regresi linier berganda menurut Walpole (1982) sebagai berikut:

$$
\mathrm{Y}^{\prime}=b_{0}+b_{1} X_{1}+\cdots+b_{k} X_{k}
$$

Keterangan: $Y^{\prime} \quad$ : variabel tidak bebas (kerapatan semai, pancang, tiang, dan pohon)

$\mathrm{b}_{0} \quad$ : intersep

$b_{k}:$ koefisien regresi

$\mathrm{X}_{\mathrm{k}}$ : variabel bebas (ketinggian, kelerengan, suhu, kelembaban, C-organik, N-total, $\mathrm{P}, \mathrm{K}$, pH, KTK, pasir, debu, dan liat)

\section{Kodisi Umum Lokasi Penelitian}

Taman Nasional Gunung Halimun Salak (TNGHS) secara administratif terbagi dalam 3 wilayah kabupaten, yaitu Kabupaten Bogor, Lebak, dan Sukabumi. Kawasan TNGHS secara geografis terbentang pada $106^{\circ} 21^{\prime}-106^{\circ} 38^{\prime}$ BT dan $6^{\circ} 37^{\prime}-6^{\circ} 51^{\prime}$ LS. Luas total \pm 113357 ha sejak menjadi kesatuan kawasan konservasi pada tanggal 10 Juni 2003 (Polosakan dan Alhamd 2012). Aksesibilitas menuju balai TNGHS dapat dijangkau dengan kendaraan darat. Perjalanan dari Jakarta menempuh waktu 3 jam dengan jarak $125 \mathrm{~km}$ melalui rute Jakarta-Bogor-Parungkuda-Kabandungan, sedangkan dari Bandung dapat ditempuh dalam 4 jam dengan jarak $152 \mathrm{~km}$ melalui rute Bandung- Sukabumi-Parungkuda-Kabandungan. Selanjutnya untuk menuju lokasi-lokasi di kawasan TNGHS seperti lokasi penelitian, sebagian besar masih berupa jalan berbatu yang lebih baik ditempuh dengan mobil jeep, sepeda motor atau harus berjalan kaki.

Kondisi lahan kawasan TNGHS mempunyai topografi bergelombang, berbukit, dan bergunung-gunung dengan ketinggian tempat berkisar antara 500-2211 m dpl (Polosakan dan Alhamd 2012). Jenis tanah di lokasi penelitian pada Resort Cikaniki merupakan asosiasi latosol coklat kemerahan dan latosol coklat, sedangkan pada Resort Kawah Ratu adalah asosiasi andosol coklat dan regosol coklat. Menurut klasifikasi Schmidt \& Ferguson (1951 dalam Hartono et al. 2007), kawasan TNGHS termasuk iklim tipe B yang terdapat 1.5-3 bulan kering. Curah hujan tahunan sebesar 4000-6000 mm/tahun, dimana bulan Oktober-April merupakan musim hujan dengan curah hujan antara 400-600 mm/bulan, sedangkan musim kemarau berlangsung antara bulan Mei-September dengan curah hujan sekitar $200 \mathrm{~mm} / \mathrm{bulan}$. Suhu rata-rata bulanan $31.5{ }^{\circ} \mathrm{C}$ dengan suhu terendah $19.7^{\circ} \mathrm{C}$ dan suhu tertinggi $31.8{ }^{\circ} \mathrm{C}$, serta kelembaban udara rata-rata $88 \%$.

Vegetasi Kawasan TNGHS mencerminkan hutan hujan pegunungan yang dibagi dalam tiga zona yaitu hutan hujan dataran rendah, hutan pegunungan bawah, dan hutan pegunungan atas. Kawasan hutan dataran rendah banyak yang telah mengalami kerusakan dan berubah menjadi hutan sekunder yang didominasi oleh tumbuhan kareumbi (Homalantus populneus), cangcaratan (Nauclea lanceolata), dan mara manggong 
(Macaranga sp.). Tumbuhan pada hutan pegunungan bawah umumnya adalah puspa (Schima wallichii), rasamala (A. excelsa) dan pasang (Quercus spp. dan Lithocarpus spp.), sedangkan untuk hutan pegunungan atas, tumbuhannya didominasi oleh jamuju (Dacrycarpus imbricatus) dan kiputri (Podocarpus neriifolius) (Sadili 2011).

Tipe ekosistem di dalam kawasan TNGHS merupakan habitat dari berbagai jenis satwa langka dan dilindungi. Menurut sejarah, kawasan ini pernah menjadi habitat Badak Jawa (Rhinoceros sondaicus) yang merupakan jenis langka dan dilindungi serta Harimau Jawa (Panthera tigris sondaicus) yang sekarang diduga sudah punah. Beberapa jenis endemik dan jenis terancam punah yang masih dapat dijumpai saat ini, di antaranya Macan Tutul Jawa (Panthera pardus melas), kucing hutan (Prionailurus bengalensis), Owa Jawa (Hylobates moloch), surilii (Presbytis comata), lutung (Trachypithecus auratus), anjing hutan (Cuon alpinus javanicus), dan sigung (Mydaus javanensis). Satwa yang terdapat di sekitar lokasi pengamatan meliputi trogon/luntur gunung, spa gunung, cicak ijo, sri gunting, beberapa jenis elang seperti elang brontok, elang ular, elang bidok, elang jawa, dan elang malam, musang, bajing, serta babi.

\section{HASIL DAN PEMBAHASAN}

\section{Komposisi Jenis Tumbuhan}

Penelitian yang dilakukan di kawasan Taman Nasional Gunung Halimun Salak memperoleh hasil sebanyak 139 jenis tumbuhan yang terdiri atas 107 marga dari 62 famili. Marga terbanyak yang ditemukan yaitu marga Ficus dan Litsea masing-masing 8 jenis, diikuti Castanopsis sebanyak 4 jenis, Dysoxylum dan Lithocarpus masing-masing sebanyak 3 jenis. Jumlah jenis pada masing-masing tingkat pertumbuhan dapat dilihat pada Tabel 1 .

Tabel 1 menunjukkan bahwa jumlah jenis tingkat semai lebih banyak dari tingkat pertumbuhan yang lain, sedangkan jumlah jenis terkecil berasal dari tingkat tiang. Kecilnya jumlah jenis pada tingkat pertumbuhan tiang kemungkinan disebabkan pada tingkat pertumbuhan sebelumnya (semai, tumbuhan bawah, dan tiang) mati sebelum menjadi tiang karena persaingan untuk mendapatkan cahaya sehingga hanya sebagian jenis toleran yang dapat bertahan hingga tingkat pohon (Irfani 2016). Banyaknya jumlah individu jenis rasamala dan jenis lain ditunjukkan pada Tabel 2.

Kerapatan jenis yang ditampilkan pada Tabel 2 menunjukkan bahwa kerapatan rasamala maupun jenis di Resort Cikaniki lebih besar dari Resort Kawah Ratu. Hal tersebut kemungkinan dikarenakan lokasi pengamatan di Resort Kawah Ratu berdekatan dengan hutan produksi terbatas dan hutan lindung yang dikelola Perum Perhutani. Selain itu, Resort Kawah Ratu juga merupakan kawasan ekowisata sehingga bisa saja terjadi gangguan dari manusia. Sebagaimana yang dinyatakan oleh Nahdi et al. (2014), bahwa kondisi lingkungan menyebabkan hadir atau tidaknya suatu spesies tumbuhan di tempat tertentu dengan tingkat adaptasi yang beragam. Selain itu, menurut Parish (2002), faktor tanah juga mempengaruhi keberadaan suatu jenis. Perbedaan yang diketahui pada kedua resort pengamatan adalah tekstur tanahnya. Resort Cikaniki didominasi oleh liat dan Resort Kawah Ratu didominasi oleh pasir, sehingga diduga rasamala di Resort Cikaniki lebih banyak karena jenis tersebut lebih cocok dengan tanah berliat.

Tabel 1 Komposisi jenis tumbuhan pada kedualokasi penelitian

\begin{tabular}{clcc}
\hline \multirow{2}{*}{ No. } & \multirow{2}{*}{ Tingkat pertumbuhan } & \multicolumn{2}{c}{ Jumlah jenis } \\
\cline { 3 - 4 } & & Resort Cikaniki & Resort Kawah Ratu \\
\hline 1 & Semai dan tumbuhan bawah & 46 & 51 \\
2 & Pancang & 24 & 29 \\
3 & Tiang & 12 & 18 \\
4 & Pohon & 40 & 32 \\
\hline
\end{tabular}


Tabel 2 Kerapatan jenis rasamala (A. excelsa) dan jenis lain pada kedua lokasi penelitian.

\begin{tabular}{lcccc}
\hline \multirow{2}{*}{ Tingkat pertumbuhan } & \multicolumn{2}{c}{ Resort Cikaniki } & \multicolumn{2}{c}{ Resort Kawah Ratu } \\
\cline { 2 - 5 } & $\begin{array}{c}\text { Rasamala } \\
\text { (ind/ha) }\end{array}$ & $\begin{array}{c}\text { Jenis lain } \\
\text { (ind/ha) }\end{array}$ & $\begin{array}{c}\text { Rasamala } \\
\text { (ind/ha) }\end{array}$ & $\begin{array}{c}\text { Jenis lain } \\
\text { (ind/ha) }\end{array}$ \\
\hline Semai & 167 & 91000 & - & 53833 \\
Pancang & - & 2080 & - & 1867 \\
Tiang & 7 & 153 & 7 & 173 \\
Pohon & 45 & 113 & 19 & 127 \\
\hline
\end{tabular}

Keterangan: ind/ha $=$ individu/hektar

\section{Jenis Dominan}

Hasil perhitungan indeks nilai penting (INP) menunjukkan terdapat beberapa jenis yang mendominasi pada masing-masing tingkat pertumbuhan dan lokasi penelitian. Tabel 3 menunjukkan jenis yang memiliki INP tertinggi di Resort Cikaniki pada tingkat semai adalah Plectronia glabra, Heritiera javanica pada tingkat pancang, Chionanthus macrocarpus pada tingkat tiang, dan A. excelsa pada tingkat pohon. Jenis yang mendominasi di Resort Kawah Ratu adalah Quercus sundaica pada tingkat semai, Euonymus javanicus pada tingkat pancang, sedangkan pada tiang dan pohon didominasi oleh Schima wallichii.Jenis dominan dengan nilai INP tertinggi adalah jenis yang memiliki daya adaptasi tinggi di lokasi penelitian. Arrijani, (2008) menyatakan, jenis yang mendominasi suatu areal dapat dinyatakan sebagai jenis yang memiliki kemampuan adaptasi dan toleransi yang lebar terhadap kondisi lingkungan.

Tabel 3 juga menunjukkan bahwa, rasamala (A. excelsa) adalah jenis yang memiliki INP urutan ke 45 pada tingkat semai, urutan 10 pada tingkat tiang, dan dominan di Resort Cikaniki pada tingkat pohon dengan INP terbesar. Rasamala juga memiliki INP urutan 9 tingkat tiang dan urutan 2 tingkat pohon di Resort Kawah Ratu setelah puspa (Schima wallichii). Hal tersebut menunjukkan lokasi penelitian masih tergolong hutan primer karena masih ditemukannya jenis-jenis primer pada hutan pegunungan bawah. Sadili (2011) menyatakan, beberapa pohon besar dari jenis-jenis yang merupakan ciri hutan pegunungan bawah yaitu puspa (S.wallichii), rasamala (A. excelsa), dan pasang (Quercus spp. dan Lithocarpus spp.). Keberadaan suatu jenis yang dominan di satu lokasi namun, tidak pada lokasi yang lain atau tidak pada tingkat pertumbuhan yang lain juga dapat disebabkan oleh berkurangnya jumlah individu suatu jenis atau hilangnya jenis dalam suatu komunitas tumbuhan (Sigiro 2013).

\section{Dominansi dan Keanekaragaman Jenis}

Tingkat keanekaragaman jenis dapat diketahui berdasarkan indeks dominansi, indeks keanekaragaman, indeks kekayaan, dan indeks kemerataan jenis. Nilai indeks dominansi dari kedua lokasi penelitian dapat dilihat pada Tabel 4.

Indeks dominansi yang digunakan memiliki kisaran dari 0 sampai 1 (Ludwig dan Reynolds 1988). Menurut Indriyanto (2012), dominansi tergolong tinggi apabila nilai ID mendekati 1 dan tergolong rendah apabila nilai ID mendekati 0. Berdasarkan klasifikasi tersebut dapat diketahui dari Tabel 4 bahwa kedua lokasi penelitian memiliki indeks dominansi yang rendah pada semua tingkat pertumbuhan. Hal ini menunjukkan bahwa dominansi tidak terpusat pada salah satu komunitas tumbuhan tertentu baik di Resort Cikaniki maupun Resort Kawah Ratu.

Nilai dominansi pada Tabel 4 tersebut berlawanan dengan keanekaragaman jenis di lokasi penelitian. Sigiro (2013) menyatakan, semakin tinggi keragaman jenis dalam suatu areal hutan akan menurunkan nilai ID, sedangkan semakin rendah keragaman jenis suatu areal hutan akan meningkatkan nilai ID sehingga terpusat pada satu jenis saja. Hidayat dan Fijridiyanto (2002) menyatakan, dominansi yang terpusat pada beberapa jenis dapat disebabkan oleh faktor internal jenis-jenis yang ditemukan. Tingkat keanekaragaman jenis juga dapat 
diketahui berdasarkan indeks keanekaragaman, indeks kekayaan, dan indeks kemerataan jenis yang disajikan pada Tabel 5.

Nilai indeks keanekaragaman jenis (H') pada Tabel 5 menujukkan bahwa keanekaragaman di Resort Cikaniki pada tingkat pertumbuhan semai, pancang, dan tiang relatif lebih rendah, sedangkan tingkat pohon relatif lebih tinggi dibandingkan dengan Resort Kawah Ratu. Menurut Lahusen et al. (2014), nilai indeks keanekaragaman yang besar mengisyaratkan terdapatnya daya dukung lingkungan yang besar terhadap kelangsungan hidup serta menunjukkan semakin stabilnya ekosistem tersebut. Tingkat keanekaragaman yang diperoleh dapat dipengaruhi oleh kecocokan jenis pada kondisi habitat hutan pegunungan di Jawa Barat (Alhamd dan Polosakan 2011). Selain itu, jumlah individu jenis yang mendominasi di Resort Cikaniki relatif lebih banyak. Hal ini dapat memunculkan persaingan antar jenis sehingga keanekaragaman menjadi relatif lebih rendah di bandingkan Resort Kawah Ratu.

Indeks kemerataan (E) merupakan suatu indeks yang dapat digunakan untuk menetapkan kemantapan atau kestabilan jenis dalam suatu komunitas (Ibadurrohmah 2016). Nilai E pada Tabel 5 hampir serupa dengan nilai H' yang menunjukkan kemerataan di Resort Cikaniki pada tingkat pertumbuhan pancang dan tiang relatif lebih rendah, tingkat semai sama, sedangkan tingkat pohon relatif lebih tinggi dibandingkan dengan Resort Kawah Ratu. Gunawan et al. (2011) menyatakan, nilai kemerataan suatu jenis ditentukan oleh distribusi setiap jenis pada masing-masing plot secara merata. Nilai kemerataan ini juga masih berkaitan dengan dominansi. Semakin tinggi nilai kemerataan maka penyebaran jenis di lokasi penelitian semakin merata sehingga dominansinya cenderung terpusat pada beberapa jenis, yang berarti nilai $\mathrm{E}$ akan berbanding terbalik dengan nilai ID (Gunawan et al. 2011; Istomo dan Pradiastoro 2011).

Indeks kekayaan jenis $(\mathrm{R})$ digunakan untuk mengetahui besarnya kekayaan jenis tumbuhan dalam suatu komunitas.Nilai R pada pada Tabel 5 juga hampir serupa dengan nilai H' dan E di Resort Cikaniki pada tingkat pertumbuhan semai, pancang, dan tiang yang relatif lebih rendah, sedangkan tingkat pohon relatif lebih tinggi dibandingkan dengan Resort Kawah Ratu. Besarnya nilai $\mathrm{R}$ tersebut didapatkan dari jumlah jenis yang ditemukan di lokasi penelitian. Ibadurrohmah (2016) menyatakan, kekayaan jenis berbanding lurus dengan banyaknya jenis dalam suatu komunitas. Semakin banyak jenis tumbuhan dalam komunitas tersebut maka akan semakin tinggi pula nilai $\mathrm{R}$ yang dimilikinya.

Tabel 3 Daftar tiga jenis tumbuhan dengan INP tertinggi pada pada kedua lokasipenelitian

\begin{tabular}{|c|c|c|c|c|c|c|}
\hline \multirow{2}{*}{$\begin{array}{l}\text { Tingkat } \\
\text { pertumbuhan }\end{array}$} & \multicolumn{4}{|c|}{ Resort Cikaniki } & \multicolumn{2}{|l|}{ Resort Kawah Ratu } \\
\hline & No & Nama spesies & $\operatorname{INP}(\%)$ & No. & Nama spesies & $\operatorname{INP}(\%)$ \\
\hline \multirow{4}{*}{ Semai } & 1 & Plectronia glabra & 13.37 & 1 & Quercus sundaica & 5.90 \\
\hline & 2 & Heritiera javanica & 4.18 & 2 & Lithocarpus elegans & 3.60 \\
\hline & 3 & Ficus sp. & 1.81 & 3 & Phoebe opaca & 2.98 \\
\hline & 19 & Altingia excelsa & 0.82 & - & Altingia excelsa & 0.00 \\
\hline \multirow{4}{*}{ Pancang } & 1 & Heritiera javanica & 41.20 & 1 & Euonymus javanicus & 19.94 \\
\hline & 2 & Litsea angulata & 18.44 & 2 & Macaranga triloba & 16.82 \\
\hline & 3 & Macaranga triloba & 18.44 & 3 & Schefflera scandens & 13.12 \\
\hline & - & Altingia excelsa & 0.00 & - & Altingia excelsa & 0.00 \\
\hline \multirow{4}{*}{ Tiang } & 1 & Chionanthus macrocarpus & 57.21 & 1 & Schima wallichii & 30.33 \\
\hline & 2 & Heritiera javanica & 46.26 & 2 & Actinodaphne glomerata & 26.22 \\
\hline & 3 & Garcinia rostrata & 43.25 & 3 & calliandra calothyrsus. & 25.04 \\
\hline & 10 & Altingia excelsa & 11.65 & 9 & Altingia excelsa & 13.59 \\
\hline \multirow{3}{*}{ Pohon } & 1 & Altingia excelsa & 109.17 & 1 & Schima wallichii & 86.69 \\
\hline & 2 & Heritiera javanica & 14.00 & 2 & Altingia excelsa & 38.64 \\
\hline & 3 & Glochidion macrocarpus & 12.79 & 3 & Quercus sundaica & 37.32 \\
\hline
\end{tabular}


Tabel 4 Nilai indeks dominansi di lokasi penelitian

\begin{tabular}{lcccc}
\hline \multirow{2}{*}{ Tingkat pertumbuhan } & \multicolumn{2}{c}{ Resort Cikaniki } & \multicolumn{2}{c}{ Resort Kawah Ratu } \\
\cline { 2 - 5 } & ID & Ket & ID & Tingkatan \\
\hline Semai & 0.044 & Rendah & 0.045 & Rendah \\
Pancang & 0.084 & Rendah & 0.048 & Rendah \\
Tiang & 0.114 & Rendah & 0.064 & Rendah \\
Pohon & 0.044 & Rendah & 0.045 & Rendah \\
\hline
\end{tabular}

Tabel 5 Nilai indeks keanekaragaman, kemerataan, dan kekayaan di lokasi penelitian

\begin{tabular}{ccccc}
\hline Lokasi & Tingkat pertumbuhan & $\mathrm{H}^{\prime}$ & $\mathrm{E}$ & $\mathrm{R}$ \\
\hline \multirow{5}{*}{ Resort Cikaniki } & Semai & 3.19 & 0.83 & 7.14 \\
& Pancang & 2.77 & 0.87 & 5.28 \\
& Tiang & 2.30 & 0.93 & 3.46 \\
& Pohon & 2.97 & 0.80 & 7.27 \\
\hline \multirow{5}{*}{ Resort Kawah Ratu } & Semai & 3.28 & 0.83 & 8.65 \\
& Pancang & 3.13 & 0.93 & 6.59 \\
& Tiang & 2.81 & 0.97 & 5.16 \\
& Pohon & 2.40 & 0.69 & 5.87 \\
\hline
\end{tabular}

\section{Struktur Tegakan}

Struktur suatu tegakan dapat dilihat secara vertikal (dari sebaran tinggi tegakannya) dan secara horizontal (dari sebaran diameter tegakan) (Dendang dan Handayani 2015). Hasil pengukuran sebaran diameter jenis rasamala dan bukan rasamala dapat dilihat pada Gambar 2.

Gambar 2 menunjukkan bahwa semakin besar ukuran diameter, maka kerapatan individunya cenderung semakin sedikit. Akan tetapi,jenis rasamala di Resort Cikaniki (Gambar 2a) memiliki kondisi yang berbeda (sebarannya tidak menyerupai "J" terbalik seperti yang lain). Kusmana dan Susanti (2015) dalam penelitiannya menyatakan, sebaran yang menyerupai huruf "J" dapat diartikan bahwa kerapatan individu pohon yang tumbuh pada masa awal pertumbuhan memerlukan banyak energi seiiring bertambahnya waktu sehingga terjadi persaingan, baik antara individu sejenis maupun beda jenis dalam mendapatkan sinar matahari yang cukup, mineral, dan pertahanan terhadap gangguan luar. Sebaran seperti ini akan menjamin keberlangsungan tegakan hutan di masa yang akan datang. Grafik pada Gambar 2a menunjukkan kerapatan individu jenis rasamala di Resort Cikaniki pada diameter 60-80 $\mathrm{cm}$ dan 80-100 $\mathrm{cm}$ lebih besar dari diameter $20-40 \mathrm{~cm}$ da $40-60 \mathrm{~cm}$. Hal tersebut berarti bahwa kondisi regenerasi jenis rasamala pada lokasi tersebut tidak normal. Sedikitnya kerapatan individu rasamala pada kelas diameter yang lebih kecil dapat disebabkan adanya persaingan dengan jenis lain pada kelas diameter yang sama.

Struktur vertikal suatu tegakan diketahui dengan mengelompokkan setiap individu pohon yang ditemukan berdasarkan kelas tinggi mengikuti stratum pohon, yakni stratum C (tinggi 4-20m), stratum B (20-30m), dan stratum A (>30m) (Kusmana et al. 2009). Berdasarkan grafik sebaran kelas tinggi pada Gambar 3, diketahui jumlah individu jenis rasamala terbanyak berada pada kelas tinggi $20-30 \mathrm{~m}$ dan pada jenis lain berada pada tinggi 4-20m.Pola sebaran kelas tinggi menunjukkan jumlah individu semakin menurun seiring bertambahnya tinggi pohon, dikarenakan sulitnya mencapai stratum A dan stratum B. Keadaan tersebut disebabkan oleh cukup lamanya waktu yang dibutuhkan untuk mencapai stratum A dan B serta persaingan yang cukup tinggi, baik untuk memperoleh nutrisi, air tanah, maupun cahaya. Namun, kondisi hutan seperti ini akan menjamin kelestarian hutan di masa yang akan datang karena jumlah individu permudaan jauh lebih banyak daripada jumlah individu pohon dewasa karena stok permudaan tersebut sangat penting untuk memelihara kemampuan regenerasi hutan (Susanti 2014). 
Grafik sebaran tinggi juga menunjukkan stratum A di Resort Cikaniki didominasi oleh jenis A. excelsa, sedangkan jenis yang ditemukan di Resort Kawah Ratu tidak ada yang mencapai tinggi di atas $30 \mathrm{~m}$. Jumlah individu rasamala pada stratum B lebih banyak dari pada stratum A (Gambar 3a) karena menurut Susanti (2014), hanya pohon yang berumur tua dari jenis pohon klimaks saja yang mampu mencapai stratum A, sehingga jumlah pohonnya sedikit dan muncul diskontinyu, sedangkan stratum B ditempati oleh pohon-pohon muda, dimana untuk mencapai tinggi 20-30 meter biasanya memerlukan waktu yang lebih pendek bila dibandingkan dengan waktu yang digunakan untuk mencapai stratum A. Banyaknya individu rasamala pada stratum B di Resort Cikaniki juga lebih banyak dari pada stratum C. Hal ini dapat dijelaskan dengan pernyataan (Soerianegara dan Lemmens, 1994) bahwa pertumbuhan semai rasamala merupakan kategori toleran (butuh naungan) dan pada beberapa tahun awal (stratum C) pertumbuhannya lambat namun setelah itu (stratum B) pertumbuhannya cepat.

\section{Penyebaran Jenis Rasamala}

Pengetahuan mengenai penyebaran sangat penting untuk mengetahui tingkat pengelompokan dari individu yang dapat memberikan dampak terhadap populasi per unit area serta untuk membantu dalam mengambil keputusan tentang metode apa yang akan digunakan untuk mengestimasi kepadatan atau kelimpahan suatu populasi (Rani 2003). Hasil analisis pola penyebaran jenis rasamala di kedua lokasi penelitian ditampilkan dalam bentuk Indeks Morisita terstandarisasi pada Tabel 6.

Penyebaran rasamala yang ditunjukkan pada Tabel 6 adalah mengelompok baik di Resort Cikaniki maupun di Resort Kawah Ratu. Hal ini sesuai dengan penelitian Arrijani et al. (2006) bahwa pola penyebaran A. excelsa adalah mengelompok. Pengelompokan menunjukkan bahwa individu-individu berkumpul pada beberapa habitat yang menguntungkan. Kejadian ini bisa disebabkan oleh tingkah laku mengelompok, lingkungan yang heterogen, atau model reproduksi (Rani 2003). Menurut Arrijani (2008), pola distribusi jenis yang mengelompok pada lokasi penelitian dikarenakan biji dari setiap tumbuhan akan jatuh di sekitar pohon induknya, sehingga jika kondisi lain menunjang maka regenerasi berupa anakan baru akan terjadi di sekitar pohon induk. Jenis pohon dengan pola penyebaran mengelompok umumnya memiliki agen dispersal berupa angin, sehingga jika ukuran buah/biji relatif besar, tidak dapat menyebar dalam radius yang lebih jauh.
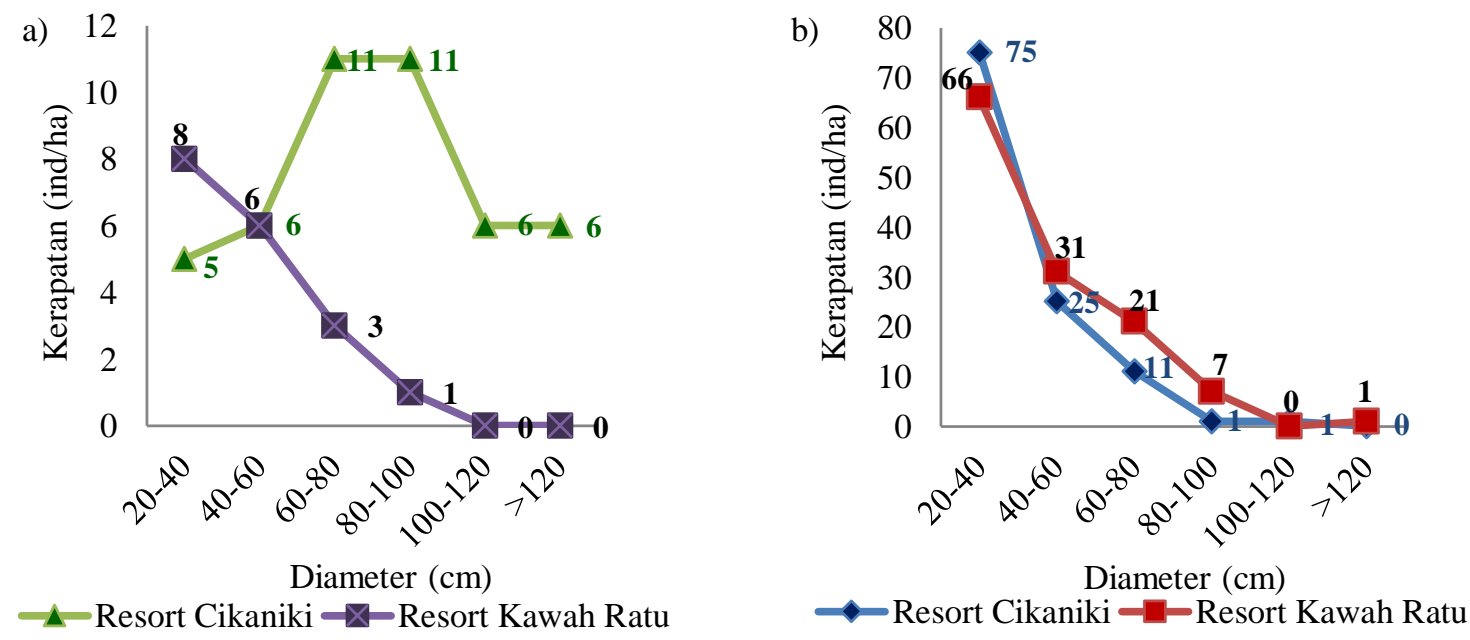

Gambar 2 Grafik sebaran kelas diameter (a) rasamala dan (b) jenis lain di lokasi penelitian 


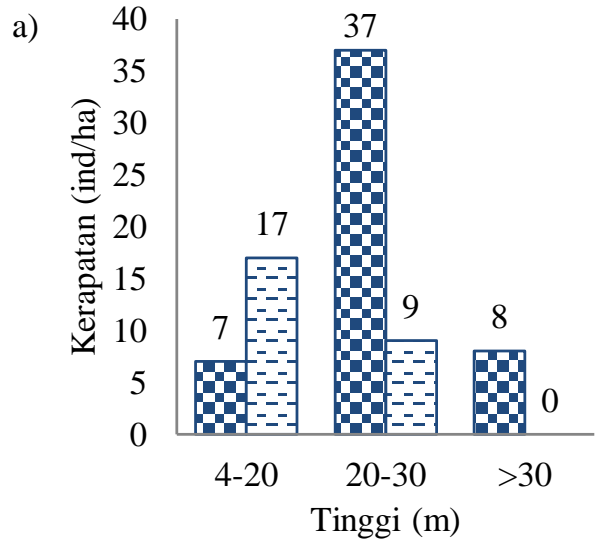

$\square$ Resort Cikaniki $\square$ Resort Kawah Ratu

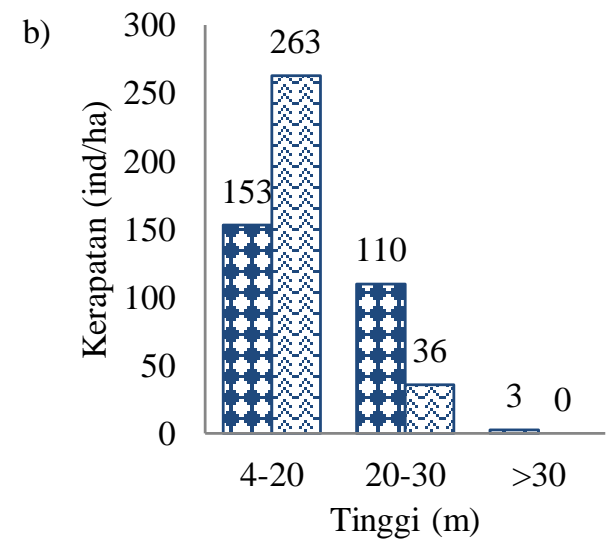

由 Resort Cikaniki $₫$ Resort Kawah Ratu

Gambar 3 Grafik sebaran kelas tinggi (a) rasamala dan(b) jenis lain di lokasi penelitian

Tabel 6 Pola penyebaran rasamala (Altingia excelsa) di lokasi penelitian

\begin{tabular}{|c|c|c|c|c|c|c|}
\hline \multirow[b]{2}{*}{ No. } & \multirow[b]{2}{*}{ Lokasi } & \multirow[b]{2}{*}{ Indeks Morisita (Id) } & \multirow[b]{2}{*}{$\begin{array}{c}\text { Uniform } \\
\text { index }(\mathrm{Mu})\end{array}$} & \multicolumn{3}{|c|}{ Indeks } \\
\hline & & & & $\begin{array}{l}\text { Clumped index } \\
\text { (Mc) }\end{array}$ & $\begin{array}{c}\text { Morisita } \\
\text { terstandarisasi } \\
\text { (Ip) }\end{array}$ & $\begin{array}{c}\text { Pola } \\
\text { penyebaran }\end{array}$ \\
\hline 1 & Cikaniki & 1.050 & 0.879 & 1.176 & 0.141 & Mengelompok \\
\hline 2 & Kawah Ratu & 1.062 & 0.665 & 1.485 & 0.063 & Mengelompok \\
\hline
\end{tabular}

\section{Hubungan Lingkungan dengan Keberadaan Rasamala (A. excelsa)}

Kehadiran suatu jenis tumbuhan di tempat tertentu dapat dipengaruhi oleh faktor lingkungan antara lain iklim, edafik (tanah), dan topografi di lokasi penelitian yang dapat dilihat pada Tabel 7. Tabel 7 menunjukkan bahwa ketinggian lokasi yang diamati termasuk dalam zona sub montana (pegunungan bawah), dimana rentang ketinggiannya adalah 1000-1500 mdpl (Hartono et al. 2007). Kondisi zona pegunungan bawah sesuai dengan habitat jenis rasamala. Sebagaimana yang dinyatakan oleh Hidayah (2011), rasamala di Jawa Barat tumbuh pada ketinggian 500-1500 mdpl dan pernyataan Sadili (2011) bahwa, jenis yang tumbuh pada hutan pegunungan bawah umumnya adalah puspa (Schima wallichii), rasamala (A.excelsa) dan pasang (Quercus spp. dan Lithocarpus spp.).

Syah dan Hariyanto (2013) menyatakan bahwa kemiringan kelerengan dibagi menjadi beberapa kelas yaitu datar (0-8\%), landai (8-15\%), agak curam (15-25\%), curam (25-45), dan sangat curam ( $\geq 45)$. Berdasarkan klasifikasi tersebut, dapat diketahui kelerengan di lokasi penelitian kelerengannya datar hingga curam. Tabel 7 juga menunjukkan suhu paling rendah terdapat pada Resort Cikaniki, sedangkan suhu tertinggi terdapat pada Resort Kawah Ratu. Tinggi rendahnya suhu kemungkinan dapat dipengaruhi oleh ketinggian tempat, penutupan oleh vegetasi, atau pengaruh sudut datangnya sinar matahari. Kadarsih (2004) menjelaskan, semakin tinggi letak suatu daerah dari atas permukaan laut, maka semakin rendah suhu udara rata-rata hariannya. Hasil penelitian Ibadurrohmah (2016) juga menyatakan, semakin tinggi intensitas cahaya matahari maka akan semakin tinggi suhunya dan sebaliknya kelembaban akan semakin rendah. Sebagaimana hasil yang ditunjukkkan pada Tabel 7, rata-rata suhu di Resort Cikaniki lebih tinggi dari Resort Kawah Ratu, sedangkan kelembaban menunjukkan sebaliknya.

Karakteristik faktor edafis dapat diketahui berdasarkan hasil analisis sifat fisik dan kimia tanah pada Tabel 8. Tabel 8 menunjukkan presentase C-organik, N-total, K, dan KTK masing-masing tergolong sangat tinggi, $\mathrm{pH}$ sangat masam, $\mathrm{P}$ tergolong sedang, serta $\mathrm{C} / \mathrm{N}$ tergolong tinggi dan sedang.Nitrogen $(\mathrm{N})$ sangat dibutuhkan 
pada tahap pertumbuhan vegetatif, seperti pembentukan tunas, perkembangan batang dan daun. Fosfor $(\mathrm{P})$ memberikan pengaruh yang menguntungkan melalui pembelahan sel, pembentukan lemak dan albumin, merangsang perkembangan akar halus dan akar rambut, ketahanan tanaman terhadap hama dan penyakit, serta pembentukan buah, bunga, dan biji (Nerotama 2014). Nilai pH tanah yang tergolong sangat masam diduga karena adanya proses dekomposisi yang sedang berlanjut (Nugroho et al. 2013). Sebagaimana nilai C-organik dan $\mathrm{pH}$ pada Tabel 8, masing-masing tergolong sangat tinggi dan sangat masam.

Tingginya bahan organik diduga menyebabkan KTK juga tinggi. Kadar bahan organik dapat diwakilkan dengan nilai KTK dan serasah yang ditemukan saat pengamatan di lapangan. Wezel et al. (2000) menyatakan, serasah pada lantai hutan dapat mempengaruhi tingkat pengkayaan tanah, dengan banyaknya serasah maka kandungan bahan organik akan lebih besar. Kelembaban udara juga mempengaruhi proses dekomposisi dari bahan organik sehingga di permukaan tanah bahan organik masih banyak ditemukan (Irfani 2016). Selain diperoleh hasil dari analisis sifat kimia tanah, diperoleh juga hasil dari analisis sifat fisika tanah berupa tekstur. Sifat fisik tanah berperan penting dalam kesuburan tanah karena jumlah dan ukuran partikel tanah menentukan porositas dan bulk density yang berperan dalam pengikatan dan pelepasan hara (Chinevu et al. 2013). Wibowo (2006) menyatakan, tekstur tanah adalah proporsi relatif dari partikel pasir, debu, dan liat di dalam tanah, yang ketiga jenis partikel tersebut adalah komponen inorganik (mineral) dari tanah dan dibedakan berdasarkan ukuran. Presentase yang diperoleh dari masing-masing kandungan pertikel tersebut dapat dilihat pada Tabel 9 .

Tabel 7 Ketinggian, kelerengan, suhu, dan kelembaban tempat tumbuh rasamala (Altingia excelsa

\begin{tabular}{cccccc}
\hline Lokasi & Nilai & $\begin{array}{c}\text { Ketinggian } \\
(\mathrm{mdpl})\end{array}$ & $\begin{array}{c}\text { Kelerengan } \\
(\%)\end{array}$ & $\begin{array}{c}\text { Suhu } \\
(0 \mathrm{C})\end{array}$ & $\begin{array}{c}\text { Kelembaban } \\
\text { Relatif }(\%)\end{array}$ \\
\hline \multirow{2}{*}{ Resort } & Minimum & 1078 & 4 & 22,3 & 74.48 \\
Cikaniki & Maksimum & 1219 & 30 & 25,1 & 88.88 \\
& Rata-rata & 1148 & 18 & 23,6 & 82.75 \\
\hline Resort & Minimum & 1162 & 3 & 22,0 & 78.00 \\
Kawah & Maksimum & 1295 & 33 & 24,3 & 90.00 \\
Ratu & Rata-rata & 1215 & 22 & 22,7 & 85.59 \\
\hline
\end{tabular}

Tabel 8 Karakteristik kimia tanah tempat tumbuh rasamala (Altingia excelsa)

\begin{tabular}{|c|c|c|c|c|c|c|c|c|}
\hline Lokasi & Ulangan & C-org (\%) & N-total (\%) & $\mathrm{C} / \mathrm{N}$ & $\mathrm{P}(\mathrm{ppm})$ & $\mathrm{K}(\mathrm{ppm})$ & $\mathrm{pH}$ & $\begin{array}{c}\text { KTK } \\
(\mathrm{cmol}(+) / \mathrm{kg})\end{array}$ \\
\hline \multirow{3}{*}{$\begin{array}{l}\text { Resort } \\
\text { Cikaniki }\end{array}$} & 1 & 17.11 & 1.05 & 16.30 & 8.30 & 61.22 & 4.1 & 44.38 \\
\hline & 2 & 12.23 & 0.57 & 21.46 & 6.46 & 56.72 & 3.9 & 34.65 \\
\hline & 3 & 21.72 & 0.84 & 25.86 & 8.46 & 113.66 & 4.2 & 55.04 \\
\hline Rata-rata & & 17.02 & 0.82 & 20.76 & 7.74 & 77.2 & 4.07 & 44.69 \\
\hline Kategori* & & $\begin{array}{l}\text { Sangat } \\
\text { tinggi }\end{array}$ & $\begin{array}{l}\text { Sangat } \\
\text { tinggi }\end{array}$ & Tinggi & Sedang & $\begin{array}{c}\text { Sangat } \\
\text { tinggi }\end{array}$ & $\begin{array}{l}\text { Sangat } \\
\text { masam }\end{array}$ & $\begin{array}{c}\text { Sangat } \\
\text { tinggi }\end{array}$ \\
\hline \multirow{3}{*}{$\begin{array}{l}\text { Resort } \\
\text { Kawah Ratu }\end{array}$} & 1 & 15.47 & 0.74 & 20.79 & 8.13 & 46.69 & 4.2 & 36.13 \\
\hline & 2 & 22.24 & 1.19 & 18.61 & 9.03 & 71.39 & 3.8 & 58.19 \\
\hline & 3 & 9.96 & 1.34 & 7.45 & 9.27 & 101.64 & 3.6 & 52.58 \\
\hline Rata-rata & & 15.89 & 1.09 & 14.55 & 8.81 & 73.24 & 3.87 & 48.97 \\
\hline Kategori* & & $\begin{array}{l}\text { Sangat } \\
\text { tinggi }\end{array}$ & $\begin{array}{l}\text { Sangat } \\
\text { tinggi }\end{array}$ & Sedang & Sedang & $\begin{array}{l}\text { Sangat } \\
\text { tinggi }\end{array}$ & $\begin{array}{l}\text { Sangat } \\
\text { masam }\end{array}$ & $\begin{array}{l}\text { Sangat } \\
\text { tinggi }\end{array}$ \\
\hline
\end{tabular}

*) Sumber: Analisis Kimia Tanah, Tanaman, Air, dan Pupuk (Eviati dan Sulaeman 2009) 
Tabel 9 Karakteristik tekstur tanah tempat tumbuh rasamala (A. excelsa)

\begin{tabular}{lcccc}
\hline \multicolumn{1}{c}{ Lokasi } & Ulangan & Pasir (\%) & Debu (\%) & Liat (\%) \\
\hline \multirow{2}{*}{ Resort Cikaniki } & 1 & 22.16 & 37.9 & 39.94 \\
& 2 & 25.65 & 30.85 & 43.5 \\
& 3 & 22.54 & 44.6 & 32.86 \\
\hline Rata-rata & & 23.45 & 37.78 & 38.77 \\
\hline Kategori* & 1 & \multicolumn{3}{c}{ Lempung Berliat } \\
\hline \multirow{2}{*}{ Resort Kawah Ratu } & 2 & 53.52 & 29.53 & 16.95 \\
& 3 & 45.19 & 22.30 & 32.51 \\
\hline Rata-rata & & 54.01 & 15.33 & 30.66 \\
\hline Kategori* & & 50.91 & 22.39 & 26.70 \\
\hline
\end{tabular}

*) Sumber: Petunjuk Teknis Analisis Kimia Tanah, Tanaman, Air, dan Pupuk (Eviati dan Sulaeman 2009)

Tabel 9 menunjukkan tekstur tanah pada Resort Cikaniki tergolong lempung berliat, sedangkan pada Resort Kawah Ratu adalah lempung liat berpasir. Pada Resort Cikaniki, presentase terbanyak adalah fraksi liat yaitu sebesar 38.77\%, sedangkan di Resort Kawah Ratu fraksi pasir yang lebih mendominasi tekstur tanahnya dengan presentase yang lebih dari setengahnya yaitu sebesar 50.91\%. Tangketasik et al. (2012) menyatakan, pasir berperan dalam aerasi tanah dan liat berperan dalam memegang air tanah, sehingga pada lokasi Resort Cikaniki memiliki kemampuan lebih dalam menyimpan air dan hara tanaman, sedangkan pada lokasi Resort Kawah Ratu memiliki aerasi tanah yang sangat baik.Tanah berlempung memiliki selisih proporsi pasir, debu, dan liat yang cenderung tidak jauh berbeda, sehingga sifatnya berada di antara tanah berpasir dan berliat, yang berarti aerasi dan tata udaranya cukup baik, serta kemampuan menyimpan dan menyediakan air untuk tanaman tinggi.

Faktor-faktor lingkungan fisik yang paling berpengaruh terhadap keberadaan rasamala dapat diketahui dari hasil perhitungan dengan menggunakan model regresi linear berganda. Variabel dependen (terikat) yang diukur adalah kerapatan jenis rasamala, sedangkan variabel independen (bebas) yang diukur adalah ketinggian, kelerengan, iklim, suhu, kelembaban, C-organik tanah, N-total, P, K, pH, KTK, \%pasir, \%debu, dan \%liat. Persamaan yang dihasilkan dari regresi linear berganda adalah sebagai berikut:

$$
\begin{array}{ll}
\mathrm{Y}_{1} & =466-0.034 \mathrm{X}_{1}+3.00 \mathrm{X}_{2}-17.0 \mathrm{X}_{3}-2.03 \mathrm{X}_{4}+7.15 \mathrm{X}_{5}+23.7 \mathrm{X}_{6} \\
\mathrm{R}^{2} & =49.9 \% \\
\mathrm{Y}_{2} & =1160-0.592 \mathrm{X}_{1}+1.68 \mathrm{X}_{2}-16.5 \mathrm{X}_{3}-1.40 \mathrm{X}_{4}+5.90 \mathrm{X}_{5}-50.2 \mathrm{X}_{6} \\
\mathrm{R}^{2} & =72.2 \%
\end{array}
$$

Keterangan:

$\mathrm{Y}_{1}=$ kerapatan rasamala Resort Cikaniki (ind/ha)

$\mathrm{Y}_{2}=$ kerapatan rasamala Resort Kawah Ratu (ind/ha)

$\mathrm{X}_{1}=$ ketinggian $(\mathrm{mdpl})$

$\mathrm{X}_{2}=$ kelerengan $\left({ }^{0}\right)$

$\mathrm{X}_{3}=\operatorname{suhu}\left({ }^{\circ} \mathrm{C}\right)$

$\mathrm{X}_{4}=$ kelembaban $(\%)$

$\mathrm{X}_{5}=$ C-organik $(\%)$

$\mathrm{X}_{6}=\mathrm{N}$-total $(\%)$ 
Berdasarkan hasil persamaan regresi di atas, faktor-faktor yang memengaruhi keberadaan jenis rasamala adalah ketinggian $\left(\mathrm{X}_{1}\right)$, kelerengan $\left(\mathrm{X}_{2}\right)$, suhu $\left(\mathrm{X}_{3}\right)$, kelembaban $\left(\mathrm{X}_{4}\right)$, C-organik $\left(\mathrm{X}_{5}\right)$, dan $\mathrm{N}$-total $\left(\mathrm{X}_{6}\right)$ dengan niai $\mathrm{R}^{2}$ berturut-turut sebesar $49.9 \%$ dan $72.2 \%$. Persamaan tersebut berarti, apabila variabel lain bernilai konstan maka nilai kerapatan rasamala di Resort Cikaniki $\left(\mathrm{Y}_{1}\right)$ dan Resort Kawah Ratu $\left(\mathrm{Y}_{2}\right)$ akan berubah dengan sendirinya sebesar nilai konstanta yaitu 466 dan 1160. Apabila variabel lain bernilai konstan, maka nilai $\mathrm{Y}_{1}$ akan berkurang sebesar 0.034 dan $\mathrm{Y}_{2}$ sebesar 0.592 setiap pertambahan ketinggian. Apabila variabel lain bernilai konstan, maka nilai $\mathrm{Y}_{1}$ akan bertambah sebesar 3.00 dan $\mathrm{Y}_{2}$ sebesar 1.68 setiap pertambahan kelerengan. Apabila variabel lain bernilai konstan, maka nilai $\mathrm{Y}_{1}$ akan berkurang sebesar 17.0 dan $\mathrm{Y}_{2}$ sebesar 16.5 setiap pertambahan suhu. Apabila variabel lain bernilai konstan, maka nilai $\mathrm{Y}_{1}$ akan berkurang sebesar 2.03 dan $\mathrm{Y}_{2}$ sebesar 1.40 setiap pertambahan kelembaban.

Faktor edafis yang masuk dalam persamaan regresi adalah C-organik dan $\mathrm{N}$-total yang diartikan bahwa, apabila variabel lain bernilai konstan, maka nilai $\mathrm{Y}_{1}$ akan bertambah sebesar 7.15 dan $\mathrm{Y}_{2}$ sebesar 5.90 setiap pertambahan kadar C-organik tanah. Apabila variabel lain bernilai konstan, maka nilai $Y_{1}$ akan bertambah sebesar 23.7 dan $\mathrm{Y}_{2}$ berkurang sebesar 50.2 setiap pertambahan kadar N-total pada tanah. Hal tersebut menunjukkan, semakin tinggi nilai ketinggian, suhu, dan kelembaban maka kerapatan rasamala akan semakin berkurang, serta dengan bertambahnya kelerengan, kandungan C-organik, dan $\mathrm{N}$-total pada tanah maka keberadaan rasamala akan semakin banyak di Resort Cikaniki dan semakin sedikit dengan bertambahnya Ntotal tanah di Resort Kawah Ratu.

Setiawan (2009) menyatakan, koefisien determinasi $\left(\mathrm{R}^{2}\right)$ bertujuan untuk mengetahui seberapa besar kemampuan variabel independen menjelaskan variabel dependen dengan nilai berkisar 0-1 yang artinya, semakin mendekati 1 maka keragaman data dependen yang dijelaskan oleh variabel independen akan semakin besar (Setiawan 2009). Nilai koefisien determinasi di Resort Cikaniki menunjukkan bahwa sebesar 0.499 atau 49.9\% keberadaan rasamala dipengaruhi oleh parameter faktor lingkungan berupa ketinggian, kelerengan, suhu, kelembaban, C-organik, dan N-total, sisanya sebesar 50.1\% ditentukan oleh faktor-faktor lain di luar parameter yang masuk dalam uji regresi. Koefisien determinasi di Resort Kawah Ratu sebesar 72.2\% keberadaan rasamala dipengaruhi oleh parameter faktor lingkungan berupa ketinggian, kelerengan, suhu, kelembaban, C-organik, dan N-total, sisanya sebesar $27.8 \%$ ditentukan oleh faktor-faktor lain.

Uji $\mathrm{F}$ pada regresi berfungsi untuk menentukan apakah secara serentak semua variabel independen mempunyai pengaruh yang bermakna terhadap variabel dependen. Apabila nilai $\mathrm{P}$ value kurang dari batas kritis penelitian atau alpha maka dapat disimpulkan bahwa variabel bebas berpengaruh nyata terhadap keberadaan rasamala. Nilai P dapat dilihat dari hasil analisis keragaman pada Tabel 10 dan Tabel 11.

Hasil analisis keragaman pada Tabel 10 dan Tabel 11 menunjukkan nilai P yang diperoleh sebesar 0.346 dan 0.054. Hubungan yang nyata dapat diperoleh apabila nilai $\mathrm{P}<0.10$ (selang kepercayaan 90\%), sehingga dapat disimpulkan bahwa variabel yang diuji di Resort Cikaniki tidak berpengaruh nyata terhadap kerapatan rasamala, sedangkan variabel yang diuji di Resort Kawah Ratu berpengaruh nyata terhadap kerapatan rasamala. Hal tersebut diduga karena faktor lain di luar model pada Resort Cikaniki memiliki pengaruh yang lebih besar dari Resort Kawah Ratu.

Tabel 10 Analisis keragaman regresi linier berganda antara keberadaan A.excelsa dengan faktor lingkungan di Resort Cikaniki.

\begin{tabular}{lccccc}
\hline Sumber keragaman & DB & JK & KT & F Hitung & P \\
\hline Regresi & 6 & 5006.7 & 834.4 & 1.33 & 0.346 \\
Sisa & 8 & 5034.5 & 629.3 & & \\
\hline Total & 14 & 10041.2 & & & \\
\hline
\end{tabular}


Tabel 11 Analisis keragaman regresi linier berganda antara keberadaan A.excelsa dengan faktor lingkungan di Resort Kawah Ratu.

\begin{tabular}{cccccc}
\hline $\begin{array}{c}\text { Sumber } \\
\text { keragaman }\end{array}$ & DB & JK & KT & F Hitung & P \\
\hline Regresi & 6 & 2400.5 & 400.1 & 3.46 & 0.054 \\
Sisa & 8 & 924.6 & 115.6 & & \\
\hline Total & 14 & 3325.1 & & & \\
\hline
\end{tabular}

Hasil analisis keragaman pada Tabel 10 dan Tabel 11 menunjukkan nilai P yang diperoleh sebesar 0.346 dan 0.054. Hubungan yang nyata dapat diperoleh apabila nilai $\mathrm{P}<0.10$ (selang kepercayaan 90\%), sehingga dapat disimpulkan bahwa variabel yang diuji di Resort Cikaniki tidak berpengaruh nyata terhadap kerapatan rasamala, sedangkan variabel yang diuji di Resort Kawah Ratu berpengaruh nyata terhadap kerapatan rasamala. Hal tersebut diduga karena faktor lain di luar model pada Resort Cikaniki memiliki pengaruh yang lebih besar dari Resort Kawah Ratu.

\section{SIMPULAN}

Rasamala (A. excelsa) di kawasan Taman Nasional Gunung Salak memiliki pola penyebaran mengelompok, baik di Resort Cikaniki maupun Resort Kawah Ratu. Faktor habitat berupa ketinggian, kelerengan, suhu, kelembaban, kandungan $\mathrm{C}$-organik tanah, dan $\mathrm{N}$-total berpengaruh nyata terhadap keberadaan rasamala (A. excelsa) di Resort Kawah Ratu dan tidak berpengaruh nyata di Resort Cikaniki.

\section{DAFTAR PUSTAKA}

Alhamd L, Polosakan R. 2011. Komposisi jenis dan struktur vegetasi di hutan kawasan Taman Nasional Gunung Halimun Salak-Sukabumi. Ber. Penel. Hayati Edisi Khusus 5A, 1-4.

Arrijani 2008. Struktur dan komposisi vegetasi zona montana Taman Nasional Gunung Gede Pangrango. Biodivesitas. 9(2): 134-141.

Arrijani, Setiadi D, Guhardja E, Qayim I. 2006. Analisis vegetasi hulu DAS Cianjur Taman Nasional Gunung Gede Pangrango. Biodiversitas. 7(2): 147-153.

Bramasto RGA. 2008. Penyebaran, regenerasi dan karakteristik habitat jamuju (Dacrycarpus imbricatus Blume) di Taman Nasional Gede Pangrango [Skripsi]. Bogor: Institut Pertanian Bogor.

Carolyn RD, Baskoro DPT, Prasetyo LB. 2013. Analisis degradasi untuk penyusunan arahan strategi pengendaliannya di Taman Nasional Gunung Halimun Salak Provinsi Jawa Barat. Globe. 15(1):39-47.

Chinevu, Nnaemeka C, Unanaonwi, Esio O, Amonum, Igba J. 2013. Physical and chemical characteristics of forest soil in Southern Guinea savanna of Nigeria. Agriculture, Forestry and Fisheries. 2(6): 229-234.

Dendang B, Handayani W. 2015. Struktur dan komposisi tegakan hutan di Taman Nasional Gunung Gede Pangrango, Jawa Barat. Biodiversitas Ekosistem. Prosiding Seminar Nasional Masyarakat Biodiversitas Indonesia 13 Juli 2015. Surakarta: Masyarakat Biodiversitas Indonesia.

Diagne N, Diouf D, Svistoonoff S, Kane A, Noba K, Franche C, Bogusz D, Duponnois R. 2013. Casuarinas in Africa: distribution, role and importance of abuscular mycorrhizal, ectomycorrihizal fungi and Frankia on plant development. Journal of Environment Management. 128:204-209.

Eviati, Sulaeman, 2009. Petunjuk Teknis: Analisis Kimia Tanah, Tanaman, Air, dan Pupuk. Bogor: Balai Penelitian Tanah.

Gunawan W, Basuni S, Indrawan A, Prasetyo LB, Soedjito H. 2011. Analisis komposisi dan struktur vegetasi terhadap upaya restorasi kawasan hutan Taman Nasional Gunung Gede Pangrango. Jurnal Pengelolaan Sumberdaya Alam dan Lingkungan. 1(2): 93- 105. 
Hartono T, Kobayashi H, Widjaya H, Suparmo M. 2007. Taman Nasional Gunung Halimun Salak: Menyingkap Kabut Gunung Halimun Salak. Bogor: Gunung Halimun Salak National Project-JICA.

Hidayah N. 2011. Daya sintas dan laju pertumbuhan rasamala (Altingia excelsa Noronha), puspa (Schima wallichii (dc.) korth), dan jamuju (Dacrycarpus imbricatus (blume) de laub.) pada lahan terdegradasi di hulu DAS Cisadane [Tesis]. Bogor: Institut Pertanian Bogor.

Hidayat S, Fijridiyanto IA. 2002. Pemanfaatan tumbuhan secara tradisional di Taman Nasional Gunung Halimun. Berita Biologi. 6(1): 125-130.

Ibadurrohmah N. 2016. Pola penyebaran dan regenerasi puspa (Schima wallichii (dc.) korth.) di Resort Selabintana Taman Nasional Gunung Gede Pangrango [Skripsi]. Bogor: Institut Pertanian Bogor.

Indriyanto. 2012. Ekologi Hutan. Jakarta: PT. Bumi Akara.

Irfani E. 2016. Pola penyebaran dan regenerasi jenis saninten (Castanopsis argentea blume) di Resort Selabintana Taman Nasional Gunung Gede Pangrango [Skripsi]. Bogor: Institut Pertanian Bogor.

Istomo dan Pradiastoro A. 2011. Karakteristik tempat tumbuh pohon palahlar gunung (Dipterocarpus retusus B1.) di kawasan hutan lindung Gunung Cakrabuana, Sumedang, JawaBarat. J. Penelitian Hutan dan Konservasi Alam. 8(1): 1-12.

Jongjitvimol T, Boontawon K, Wattanachaiyingcharoen W, Deowanish S. 2005. Nest dispersion of a stingless bee species (Trigona collina Smith 1857) Apidae, Meliponinae in a mixed deciduous forest in Thailand. The Natural History Journal of Chulalongkorn University. 5(2), 69-71.

Kadarsih S. 2004. Performans Sapi Bali berdasarkan ketinggian tempat di daerah transmigrasi Bengkulu: 1. Perfomans pertumbuhan. Jurnal Ilmu-ilmu Pertanian Indonesia. 6(1): 50-56.

Kusmana C. 1997. Metode Survey Vegetasi. Bogor: PT Penerbit Institut Pertanian Bogor.

Kusmana C, Saharjo BH, Sumawinata B, Onrizal, Kato T, 2009. Komposisi jenis dan struktur hutan hujan tropika dataran rendah di Taman Nasional Danau Sentarum, Kalimantan Barat. Jurnal Ilmu Pertanian Indonesia. 14(3): 149-157.

Kusmana C, Susanti S. 2015. Komposisi dan struktur tegakan hutan alam di Hutan Pendidikan Gunung Walat.Sukabumi. Jurnal Silvikultur Tropika. 5(3): 210-217.

Lahusen MR, Naharuddin, Sustri. 2014. Keanekaragaman jenis vegetasi tepian Sungai Kaili Desa Labuan Kungguma Kecamatan Labuan. Warta Rimba. 2(1): 136-144.

Ludwig JA, JF Reynolds. 1988. Statistical Ecology. New York: John Wiley and Sons.

Magurran AE. 2004. Measuring Biological Diversity. Oxford: Blackwell Publising.

Morisita M. 1959. Measuring of the dispertion of individuals and analysis of the distributional patterns. Memories of the Faculty of Science, Kyushu University. Series E (Biology). 2(4): 215-235.

Mueller-Dombois D, Ellenberg H. 1974. Aims and Method of Vegetation Ecology. New York: Jhon Wiley and Sons.

Nahdi MS, Marsono D, Djohan TS, Baequni M. 2014. Struktur komunitas tumbuhan dan faktor lingkungan di lahan kritis, Imogiri Yogyakarta. J. Manusia dan Lingkungan. 21(1): 67-74.

Nerotama S. 2014. Pengaruh dua jenis pupuk daun dan dosis pupuk NPK terhadap pertumbuhan vegetatif awal tanaman jambu biji (Psidium guajava L.) kultivar Citayam [Skripsi]. Bandar Lampung: Universitas Lampung.

Nugroho TC, Oksana, Aryanti E. 2013. Analisis sifat kimia tanah gambut yang dikonversi menjadi perkebunan kelapa sawit di Kabupaten Kampar. Jurnal Agroteknologi. 4(1): 25-30.

Parish RL. 2002. Rate setting effects on fertilizer spreader distribution patterns. Applied Engineering in Agriculture. 18(3): 301-306.

Polosakan R, Alhamd L. 2012. Keanekaragaman dan komposisi jenis pohon di Hutan Pameumpeuk Taman Nasional Gunung Halimun Salak Kabupaten Sukabumi. J. Teknologi Lingkungan edisi khusus. 53-59. 
Pramono AAD, Djam'an F. 2002. Sistem Informasi Perbenihan Tanaman Hutan: Informasi Singkat Benih. Bogor: Balai Penelitian dan Penelitian dan Pengembangan Teknologi Perbenihan.

Rani C. 2003. Metode pengukuran dan analisis pola spasial (dispersi) organisme bentik. Jurnal Protein. 19: 1351-1368.

Sadili A. 2011. Keanekaragaman, persebaran dan pemanfaatan jenis-jenis anggrek (Orchidaceae) di Resort Citorek di Taman Nasional Gunung Halimun Salak Jawa Barat. Biosfera. 28(1):15-22.

Setiawan E. 2009. Kajian hubungan unsur iklim terhadap produktivitas cabe jamu (Piperretrofractum Vahl) di Kabupaten Sumenep. Agrovigor. 2(1): 1-7.

Sigiro AR. 2013. Struktur tegakan dan regenerasi alami hutan di Pulau Siberut, Sumatera Barat [Skripsi]. Bogor: Institut Pertanian Bogor.

Soerianegara I, Lemmens RHMJ. 1994. Plant Resouces of South-East Asia. Bogor: Major commercial timbers. PROSEA.

Susanti S. 2014. Komposisi jenis dan struktur tegakan regenerasi alami di Hutan Pendidikan Gunung walat, Sukabumi [Skripsi]. Bogor: Institut Pertanian Bogor.

Syah MW, Hariyanto T. 2013. Klasifikasi kemiringan lereng dengan menggunakan pengembangan sistem informasi geografis sebagai evaluasi kesesuaian landasan pemukiman berdasarkan undang-undang tata ruang dan metode fuzzy. Jurnal Teknik Pomits. 10(10): 1-6.

Tangketasik A, Wikarniti NM, Soniari NN, Narka IW. 2012. Kadar bahan organik tanah pada tanah sawah dan tegalan di Bali serta hubungannya dengan tekstur tanah. Agrotrop. 2(2): 101-107.

Walpole RE. 1982. Pengantar Statistika Edisi 3. Sumantri B, penerjemah, Terjemahan dari: Introduction to Statistics 3rd Edition. Jakarta: Gramedia Pustaka Utama.

Wezel A, Rajot JL, Herbrig C. 2000. Influence of shrubs on soil characteristic and their functional in Sahelian ecosystems in semi-arid Niger. Journal of Arid Environments. 44(4): 383-398.

Wibowo C. 2006. Hubungan antara keberadaan saninten (Castanopsis argentea Blume) dengan beberapa sifat tanah: kasus di Taman Nasional Gunung Gede Pangrango Jawa Barat [Disertasi]. Bogor: Institut Pertanian Bogor.

Yusuf R. 2004. Keanekaragaman jenis pohon pada hutan terganggu di daerah koridor Taman Nasional Gunung Halimun. Berita Biologi. 7(1):41-50. 